SPIES WITHOUT CLOAKS 



\section{SPIES WITHOUT CLOAKS}

THE KGB'S SUCCESSORS

AMY KNIGHT 
Copyright (C) 1996 by Amy Knight

Published by Princeton University Press, 41 William Street,

Princeton, New Jersey 08540

In the United Kingdom: Princeton University Press,

Chichester, West Sussex

All Rights Reserved

Library of Congress Cataloging-in-Publication Data

Knight, Amy 1946-

Spies without cloaks : The KGB's successors / Amy Knight.

p. $\mathrm{cm}$.

Includes index.

eISBN 1-4008-0450-7

1. Secret service-Russia (Federation)

2. Russia (Federation). Ministerstvo bezopasnosti.

I. Title.

HV8227.2.A3K59 1996

363.2'83'0947—dc20 95-26281

This book has been composed in Sabon 
To all those in Russia who have courageously fought to reform the KGB and its successors 
